УДК 373.5.015.31:502/504]:005.963.3

DOI: https://doi.org/10.33989/2075-146x.2019.23.183203

\title{
ЕДУАРД ЄВТУШЕНКО
}

Криворізький державний педагогічний університет

\section{РОЗВИТОК ПІЗНАВАЛЬНОГО ІНТЕРЕСУ ДО БІОЛОГІЇ В ПРОЦЕСІ НАУКОВО-ДОСЛІДНИЦЬКОЇ ДІЯЛЬНОСТІ СТАРШОКЛАСНИКІВ ЗАСОБАМИ ЕКОЛОГІЧНОЇ ЕКСКУРСІї}

\begin{abstract}
Розвиток пізнавального інтересу в процесі науково-дослідницької діяльності вимагає пошуку нових підходів до удосконалення ï змісту, форм, методів, засобів, спрямованих на реалізацію принципу активності в учінні, який має визначальне значення в сучасних умовах, оскільки дозволяє не тільки програмувати результат навчання, розвитку й виховання школярів, але й формувати ставлення учнів до власне пізнавальної діяльності.

Здійснення науково-дослідної діяльності старшокласниками підвищує рівень пізнавального інтересу до загальної біології. Розроблена автором програма факультативу «Екологія угруповань» та тематична екскурсія «Природа угруповань» дозволяє визначити і реалізувати завдання підвищення рівня пізнавального інтересу в процесі науково-дослідницької діяльності учнів 11 класів. Важливим складником цього процесу $\epsilon$ використання методик геоботанічного дослідження рослинності та виконання науково-дослідницьких завдань під час проведення екологічної екскурсії на степовий курган. Виконання таких завдань дозволить розширити пізнавальні властивості учнів і їхній інформаційний рівень, підтримувати інтерес до отримання нових знань, підвищити ефективність сприйняття інформації за рахунок індивідуального темпу роботи, розвинути індивідуальний інтерес до предмета, створити умови для розвитку абстрактного мислення, самостійної роботи учня 3 отриманим у процесі науково-дослідницької діяльності матеріалом.
\end{abstract}

Ключові слова: науково-дослідницька діяльність; пізнавальний інтерес; екологічна екскурсія

Проблема розвитку пізнавального інтересу вимагає пошуку шляхів до подальшого удосконалення змісту, форм, методів, засобів науково-дослідницької діяльності, спрямованих на реалізацію принципу активності в учінні, який має визначальне значення в сучасних умовах; адже від якості учіння залежить не тільки результат навчання, розвитку й виховання школярів, але й формування ставлення учнів до власне пізнавальної діяльності.

Спостереження за роботою вчителів біології, аналіз результатів самостійної роботи учнів із загальної біології показали, що пізнавальна активність більшості учнів знаходиться на репродуктивному рівні. Один із шляхів позитивної зміни ситуації, що склалася нині, бачиться в удосконаленні форм та методів навчальної і позанавчальної роботи зі школярами, надання їй дослідницького сенсу. Така робота повинна надавати науково-дослідницькій діяльності учнів творчого, дослідницького спрямування, що приваблює їх, приносить задоволення, а також викликає бажання працювати, відшукувати нові знання.

Становлення в учнів старших класів пізнавального інтересу до біології сприятиме розвитку дослідницьких навичок, розвитку спостережливості у вивченні явищ природи, закріпленню набутих знань. Важливу роль тут відіграють екологічні екскурсії, які дають можливість в конкретних умовах науково-дослідницької діяльності спостерігати результати впливу антропогенних факторів на природу і встановлювати зв'язок між вивченим теоретичним матеріалом і місцевими проблемами довкілля.

Теоретичні основи розвитку пізнавальної активності школярів як однієї з основних передумов успішного навчання розробляли відомі вітчизняні вчені 3. А. Абасова (1989), В. К.Буряк \& Л. В. Кондрашова (1995), Ю. К. Бабанський (1988), Т. І. Шамова (1982), Г. І. Щукіна (1972) та інші. Проте, як свідчить практика, сьогодення вимагає нових підходів до цієї проблеми, що враховували б специфіку сучасного освітнього середовища, вимоги сьогодення і майбутнього, дозволяли узгодити наявний досвід із можливостями педагогічного процесу в сучасному 3 СО.

У цьому контексті проблема розвитку пізнавального інтересу учнів до біології в процесі науково-дослідницької діяльності під час проведення екскурсії з використанням геоботанічних методів $є$ достатньо актуальною, адже сприятиме формуванню інтересу до пізнання, спонукатиме до творчого пошуку, вимагатиме нестандартних знань та вмінь учнів. Тож мета нашого дослідження - виявити ефективні методи та прийоми розвитку пізнавального інтересу до біології в процесі науково-дослідницької діяльності засобами геоботанічних досліджень степових курганів. Завдання, що постають на цьому шляху, передбачають, зокрема, з'ясування можливостей науководослідницької діяльності у підвищенні пізнавального інтересу до загальної біології в учнів 11-х класів у процесі геоботанічного дослідження рослинності степового кургану під час екскурсії.

Пізнавальна діяльність людини являє собою досить складний процес взаємодії зовнішніх і внутрішніх впливів $\mathrm{i}$ завжди пов'язана з яким-небудь об'єктом, завданням, завжди цілеспрямована, - у першу чергу, на ті об'єкти і явища, які мають життєве значення й цікаві для особистості.

На думку О. М. Гринько (1998, с. 72-75), до структури пізнавальної діяльності входять пізнавальна потреба, пізнавальний інтерес, а також потреби у самовираженні особистості, самовдосконаленні, як і загальна спрямованість особистості на навчання, що забезпечується конкретними мотивами навчальної діяльності. 
Пізнавальний інтерес - вибіркова спрямованість особистості на предмети і явища навколишньої дійсності, що характеризується постійним прагненням до пізнання. Він детермінований мотивами діяльності і характеризується параметрами стійкості, локалізації та усвідомленості (Абасова, 1989, с. 40-43; Степанов, \& Фіцула, 2003).

Систематично зміцнюючись і розвиваючись, пізнавальний інтерес позитивно впливає не тільки на процес і результат діяльності, але і на перебіг психічних процесів - мислення, уяви, пам'яті. Активізація пізнавальної діяльності без розвитку пізнавального інтересу неможлива, тому в процесі навчання необхідно систематично збуджувати, розвивати і зміцнювати пізнавальний інтерес і як важливий мотив навчання, і як стійку рису особистості (Богоявленская, 1983; Лозовая, \& Троцко, 1989, с. 25).

У контексті освітньої діяльності пізнавальний інтерес виступає, насамперед, як інтерес до навчальної діяльності, до отримання знань, до науки. Він спрямований не тільки на процес пізнання, але і на його результат, а це завжди пов'язано з прагненням до мети, з реалізацією ії, подоланням труднощів, 3 вольовою напругою і зусиллям. Тож пізнавальний інтерес тісно пов'язаний із вольовими процесами, що сприяють організації, перебігу і завершенню діяльності.

Цілком закономірно, що проблема пізнавального інтересу в навчанні здавна привертала увагу дидактів. У найрізноманітніших трактуваннях проблеми в класичній педагогіці головну функцію його всі бачили в тім, щоб наблизити учня до навчання, заохотити, «зачепити» так, щоб навчання для учня стало бажаним, потребою, без задоволення якої немислимо його благополучне формування як особистості (Волкова, 2001, с. 113-115; Бабанский, 1988, с. 171-172)

Пізнавальний інтерес потрібно визнавати одним із найзначущіших факторів навчального процесу, що, безперечно, впливає як на створення світлої й радісної атмосфери навчання, так і на його ефективність. Саме він лежить в основі науково-дослідницької діяльності учнів, i водночас поглиблюється іiі засобами, набуває конструктивного змісту, сприяє формуванню свідомого ставлення до дійсності, явищ іï динаміки і трансформації. За наявності пізнавальних інтересів навчання стає особистісно близькою, життєво важливою діяльністю, у якій сам школяр зацікавлений.

Методика вивчення й формування пізнавальних інтересів учнів - питання, рівною мірою актуальне як для дослідження окресленої теоретичної проблеми, так і для практики навчання й виховання. До методів дослідження пізнавального інтересу учнів підійдемо, насамперед, із позицій загальних засад виховання, у фарватері якої виявляються найважливіші тенденції формування й розвитку будь-якої властивості особистості.

Процес формування пізнавального інтересу відбувається в діяльності, структура якої (ії завдання, зміст, способи й мотиви) становлять об'єктивну основу його розвитку.

Ефективність діяльності щодо формування пізнавального інтересу підлітків залежить від педагогічно правильної іï організації, використання iï об'єктивних умов і внутрішніх можливостей особистості учня. До останніх належать потреби, система цілей і завдань особистості, їі позиції, на основі чого виникають складні ставлення до предметного світу й до інших людей, зростає рівень загального розумового розвитку, виникають орієнтири для самостійного пізнання оточуючої дійсності.

До сфери пізнавального інтересу включаються не тільки знання, що здобуваються школярами, але й сам процес здобуття знань, процес навчання в цілому, що дозволяє оволодівати все новими необхідними способами пізнання й сприяє постійному поступальному руху школяра.

Пізнавальний інтерес являє собою сплав найважливіших для розвитку особистості психічних процесів. У інтелектуальній діяльності, що відбувається під впливом пізнавальних інтересів, проявляється:

- активний пошук;

- здогад;

- дослідницький пошук;

- готовність до рішення завдання.

Важливою особливістю пізнавального інтересу є також і те, що центром його здатне стати таке пізнавальне завдання, яке вимагає від людини активної пошукової або творчої роботи, а не елементарного орієнтування на новизну й несподіванку.

Усвідомлення пізнавальних інтересів учнів дозволяє їм віддавати перевагу навчальним завданням більш складного характеру, до чого вони прагнуть при вільному виборі, в природній і експериментальній ситуаціях, що, безперечно, може бути реалізоване в процесі науково-дослідницької діяльності в процесі навчання загальній біології.

Згідно з шкільною програмою з біології для 11-го класу (2016) доцільним є створення факультативу «Екологія угруповань» із наведеним нижче тематичним планом (див. табл. 1). Навчальні екскурсії $є$ його органічним складником.

Так, у межах програми факультативу «Екологія угруповань» нами розроблена тематична екскурсія «Природа угруповань» 3 елементами науково-дослідницької діяльності у вигляді різноманітних завдань. Проведення геоботанічних досліджень рослинності степового кургану учнями, як складника науково-дослідницької діяльності під час екскурсії, дозволяє визначити зміну рівня пізнавального інтересу в ході науково-дослідницької діяльності.

Основу науково-дослідницької діяльності складають опрацьовані методики вивчення фітоценозів, такі як: визначення кількісного співвідношення видів, флористичного складу фітоценозів, його структурного почленування, вивчення та аналіз рослинного покриву місцевості.

Для самостійного виконання науково-дослідницьких завдань, а також для перенесення спорядження учні поділяються на невеликі групи по 3-4 особи. Науково-дослідницькі завдання для самостійної роботи учнів готуються на картках. Кожна група отримує картку з двома завданнями, що передбачають вивчення різних об'єктів, найчастіше рослинних і тваринних, та окремих явищ. 
Тематичний план факультативу «Екологія угруповань» (11-й клас; 34 години)

Таблиця 1

\begin{tabular}{|c|c|c|c|c|c|}
\hline $\begin{array}{l}\text { № } \\
\text { п/ா }\end{array}$ & Тема & $\begin{array}{l}\text { Кількість } \\
\text { годин }\end{array}$ & Лекції & Практичні заняття & Екскурсї̈ \\
\hline 1 & Природа угруповань & 5 & 2 & 1 & 2 \\
\hline 2 & Властивості угруповань & 7 & 2 & 3 & 2 \\
\hline 3 & Учення про консорції & 2 & 1 & 1 & 2 \\
\hline 4 & Трофічні зв’язки та рівні & 7 & 2 & 3 & 2 \\
\hline 5 & Потік енергії трофічними ланцюгами & 3 & 1 & 2 & 2 \\
\hline 6 & Екологічні піраміди & 7 & 1 & 4 & 2 \\
\hline 7 & Екологічна ніша & 2 & 2 & 2 & 2 \\
\hline
\end{tabular}

Зміст карток із завданнями:

Поділити курган на 4 ділянки (північ, південь, захід, схід).

Визначити на кожній $з$ ділянок домінуючі рослини.

Провести підрахунок середнього значення та питомої кількості домінуючих рослин на 1 м2 на кожній ділянці.

Виміряти висоти домінуючих рослин на кожній ділянці та визначити середні величини.

Зібрати зразки рослин для гербарію.

Сфотографувати кожну ділянку та рослини.

У підсумку, зібрані матеріали і результати спостережень, проведених усіма учнями, дозволять встановити загальні закономірності існування та видовий склад рослинності степового кургану; зробити висновок про різноманітність рослинності степового кургану. Результати роботи кожної групи були представлені нею в контексті загальної екскурсії, яку розпочав педагог і яку мали завершити учні на основі зібраних ними даних.

Науково-дослідницька діяльність під час проведення екскурсії за розробленим змістом та планом 3 учнями 11 класів Христофорівської ЗОШ Дніпропетровської області дозволила підвищити рівень їхнього пізнавального інтересу як стосовно власне біологічної та екологічної інформації, що здобувалася дедуктивним та індуктивним шляхом, так і стосовно географії, історії рідного краю тощо. Було констатовано, що застосування екскурсій у процесі навчання загальній біології з використанням науково-дослідницьких завдань дозволяє:

- розширювати пізнавальні властивості учнів і їхній інформаційний рівень;

- створювати умови для розвитку абстрактного мислення;

- працювати в індивідуальному для школяра темпі сприйняття навколишнього середовища та навчальної інформації;

- розвивати індивідуальний інтерес до предмету;

- створювати умови до спонукання самостійної роботи учня з навчальним матеріалом;

- підтримувати інтерес до отримання нових знань.

Спостереження за роботою учнів у процесі екскурсії з науково-дослідницькими елементами, опитування, проведені перед іï організацією та в кінці роботи (після звіту), показали, що їхня індивідуальна і загальна активність у здобутті й упорядкуванні інформації була значно вищою, ніж під час проведених раніше екскурсій традиційної форми, коли інформація отримувалась без залучення самостійних досліджень. Зокрема, якщо на питання «Чи могли б ви запропонувати дидактичний проект для учнів середніх класів, спрямований на вивчення природи рідного краю? Якого спрямування?» до початку екскурсії ствердно відповіли близько 70\% учнів, а тему проекту змогли сформулювати лише близько 30\%, то по іiі завершенні ідеї щодо реалізації такого проекту висловили всі без винятку одинадцятикласники, продемонструвавши досить глибоке розуміння можливостей науково-дослідницької роботи і спираючись на особистий досвід ії здійснення.

Висновки. Таким чином, вдосконалення організаційних форм навчальної роботи при навчанні загальної біології повинно забезпечувати активну теоретичну й практичну діяльність учнів в процесі науково-дослідницької діяльності, акцентуючись не тільки на придбанні загальних знань з предмету, але й на поглибленому засвоєнні матеріалу та формуванні пізнавального інтересу шляхом проведення екскурсій. 
Найбільш важливими факторами процесу активізації пізнавальної діяльності є їі наочність, емоційність, індивідуалізація, самостійність, що повинні знайти під час екскурсії належне організаційне забезпечення.

Використання для здійснення науково-дослідницької діяльності екскурсій з вивчення рослинності степового кургану дозволяє найбільш повно ознайомити учнів з предметом навчання, розширити їхні пізнавальні можливості, розвинути індивідуальний інтерес до загальної біології, спонукати до подальшої самостійної роботи.

\section{Список використаних джерел}

Абасова, 3. А. (1989). Познавательная активность школьников. Советская педагогика, 7, 40-43.

Бабанский, Ю. К. (Ред.). (1988). Педагогика: учеб: пособ. для студ. пед. ин-тов. 2-е изд., доп. и перераб. Москва: Просвещение.

Богоявленская, Д. П. (1983). Интеллектуальная активность как проблема творчества. Ростов на Дону: Изд-во Ростовського ун-та.

Буряк, В. К., \& Кондрашова, Л. В. (1995). Активизачия учебной деятельности школьников. Кривой Рог: КГПИ.

Волкова, Н. П. (2001). Педагогіка: посіб. для студ. вищих навч. закладів. Київ: Академія.

Гринько, О.М. (1998). Проблеми стимулювання самостійної навчально-пізнавальної активності учнів. Рідна школа, 5 , $72-75$.

Лозовая, В. И., \& Троцко, А. В. (1989). Познавательная активность как педагогическая проблема. Советская педагогика, 11,25 .

Програма з біології для для 10-11 класів загальноосвітніх навчальних закладів. Рівень стандарту (зі змінами, затвердженими наказом МОН України № 826 від 14.07.2016). URL: http://mon.gov.ua/.

Степанов, О. M, \& Фіцула, М. М. (2003). Основи психологи і педагогіки: посібник. Київ: Академвидав.

Шамова, Т. И. (1982). Активизация учения школьников. Москва: Педагогика.

Щукина, Г. И. (1972). Проблема познавательного интереса в педагогике. Москва: Педагогика.

\section{References}

Abasova, Z. A. (1989). Poznavatelnaia aktivnost shkolnikov [Cognitive activity of schoolchildren]. Sovetskaia pedagogika [Soviet pedagogy], 7, 40-43 [in Russian].

Babanskii, Iu. K. (Ed.). (1988). Pedagogika [Pedagogy]: ucheb: posob. dlia stud. ped. in-tov. 2-e izd., dop. i pererab. Moskva: Prosveshchenie [in Russian].

Bogoiavlenskaia, D. P. (1983). Intellektualnaia aktivnost kak problema tvorchestva [Intellectual activity as a problem of creativity]. Rostov na Donu: Izd-vo Rostovskogo un-ta [in Russian].

Buriak, V. K., \& Kondrashova, L. V. (1995). Aktivizatciia uchebnoi deiatelnosti shkolnikov [Revitalization of educational activities of students]. Krivoi Rog: KGPI [in Russian].

Volkova, N. P. (2001). Pedahohika [Pedagogy]: posib. dlia stud. vyshchykh navch. zakladiv. Kyiv: Akademiia [in Ukrainian].

Hrynko, O. M. (1998). Problemy stymuliuvannia samostiinoi navchalno-piznavalnoi aktyvnosti uchniv [Problems of stimulating students' independent educational and cognitive activity]. Ridna shkola [Home school], 5, $72-75$ [in Ukrainian].

Lozovaia, V. I., \& Trotcko, A. V. (1989). Poznavatelnaia aktivnost kak pedagogicheskaia problema [Cognitive activity as a pedagogical problem]. Sovetskaia pedagogika [Soviet pedagogy], 11, 25 [in Russian].

Stepanov, O. M, \& Fitsula, M. M. (2003). Osnovy psykholohy i pedahohiky [Fundamentals of psychology and pedagogy]: posibnyk. Kyiv: Akademvydav [in Ukrainian].

Shamova, T. I. (1982). Aktivizatciia ucheniia shkolnikov [Revitalization of schoolchildren]. Moskva: Pedagogika [in Russian].

Shchukina, G. I. (1972). Problema poznavatelnogo interesa v pedagogike [The problem of cognitive interest in pedagogy]. Moskva: Pedagogika [in Russian].

\section{YEVTUSHENKO E.}

Kryvyi Rih state pedagogical university, Ukraine

\section{DEVELOPMENT OF COGNITIVE INTEREST IN BIOLOGY IN THE PROCESS \\ OF SCIENTIFICALLY- RESEARCH ACTIVITY OF SENIOR PUPILS BY FACILITIES OF ECOLOGICAL EXCURSION}

Problem of development of cognitive interest in the process ofscientifically-research activity requires to the search of thenew going near the improvement of her maintenance, forms, methods, facilities sent to realization of principle of activity, that has a qualificatory value in modern terms, asallows not only to program the result of studies, developmentand education of schoolchildren but also forming of relation ofstudents to own cognitive activity. 
Cognitiv interest $i$ an important condition and one ofmeaningful factors of efficiency of studies of general biologyand process of scientifically-research activity of senior pupils.

The level of cognitive interest promotes realization ofresearch activity senior pupils to general biology. Yes, worked out program of optional class "Ecology ofgroupments" and thematic excursion "Nature of groupments"allows to define and realize the task of increase of level ofcognitiv interest in the process of scientificallyresearchactivity of students 11 classes. The important constituent ofthis process is the use of methodologies of geobotanicalresearch of vegetation and implementation of scientificallyresearch tasks during realization of ecological excursion on asteppe burial mound. Implementation of such tasks by seniorpupils independently under the direction of teacher with nextgeneralization of the got results and his analysis will allow toextend cognitive properties of students and their informativelevel, support interest in the receipt of new knowledge, promote efficiency of perception of information due to theindividual rate of work, develop individual interest in an object, to create terms for development of abstract thought, independent work of student with got, in the process ofscientifically-research activity.

Keywords: scientifically research activity; cognitive interest; ecological excursion

Стаття надійшла до редакції 14.02.2019 p.

УДК 796.894:378

DOI: https://doi.org/10.33989/2075-146x.2019.23.183206

ВАЛЕРІЙ ЖАМАРДІЙ

ORCID ID 0000-0002-3579-6112

Українська медична стоматологічна академія, м. Полтава, Україна

\title{
МОДЕЛЮВАННЯ МЕТОДИЧНОЇ СИСТЕМИ ЗАСТОСУВАННЯ ФІТНЕС-ТЕХНОЛОГІЙ В ОСВІТНЬОМУ ПРОЦЕСІ 3 ФІЗИЧНОГО ВИХОВАННЯ СТУДЕНТІВ
}

\begin{abstract}
Основний зміст статті полягає у моделюванні методичної системи застосування фітнес-технологій в освітньому процесі з фізичного виховання студентів. Модель методичної системи застосування фітнестехнологій розглядається нами як описова модель освіти, оскільки вона розробляється вперше в системі фізичного виховання, фізкультурно-оздоровчій діяльності та може дати уявлення про мету, завдання, структуру й основні елементи фізкультурно-оздоровчої діяльності засобами фітнес-технологій. З'ясовано, що мету, функції, принципи фізкультурно-оздоровчої діяльності студентів можна розглядати як зміст $\mathrm{i}$ технологію, організаційно-методичне забезпечення, психолого-педагогічні умови функціонування методичної системи. Визначено підсистеми методичної системи застосування фітнес-технологій: 1) освітній процес із фізичного виховання та вся фізкультурно-оздоровча діяльність у ЗВО спрямовані на збереження $\mathrm{i}$ зміцнення здоров'я студентів, набуття ними навичок дотримання здорового способу життя, активного проведення дозвілля; 2) дидактичні та методичні принципи застосування фітнес-технологій спрямовані на всебічний розвиток і фізичну підготовленість студентів; 3) загальна фізична підготовка спрямована на підвищення працездатності студентів і готовності для подальшої життєдіяльності; 4) зміст, структура й функції фітнес-технологій розглядаються в контексті забезпечення необхідного рівня рухової активності студентів. Побудова і впровадження методичної системи застосування фітнес-технологій вимагає вирішення методологічних, змістових, психолого-педагогічних, методичних і організаційних завдань.
\end{abstract}

Ключові слова: методична система; модель; студенти; фізичне виховання; фітнес-технології

Постановка проблеми. Функціонування методичної системи застосування фітнес-технологій обумовлено рядом нових чинників, які виникли у фізичному вихованні в зв'язку з новими вимогами до освітніх програм підготовки фахівців, ліквідацією дисципліни «Фізичне виховання» як обов'язкової у навчальному плані 3ВО, необхідністю збереження стану здоров'я, рівня фізичної підготовленості та працездатності сучасної молоді, створення нового фізкультурно-оздоровчого середовища в освітньому процесі ЗВО України.

Аналіз досліджень і публікацій. Модель методичної системи застосування фітнес-технологій створювалася на основі розробленої концепції, яка опирається на основи теорії і методики фізичного виховання (Круцевич, 2008), теорії професійної підготовки фахівців у галузі фізичної культури і спорту (Карпюк, 2008; Сущенко, 2003; Тимошенко, 2008), а також на рекомендаціях різних компонентів цілісної системи підготовки фахівця до життєдіяльності (Грибан, 2011a; Грибан, 2011b; Круцевич, 2008).

Мета статті полягає у моделюванні методичної системи застосування фітнес-технологій в освітньому процесі 3 фізичного виховання студентів.

Виклад основного матеріалу. Модель - це знакова система, за допомогою якої можна відтворити дидактичний процес як предмет дослідження, показати в цілісності його структуру, функціонування і зберегти цю цілісність на всіх етапах дослідження. Шляхом моделювання можна відтворити не лише статику дидактичного процесу, а його динаміку. Наявність науково обгрунтованої моделі навчального процесу дозволяє прогнозувати його розвиток. А це особливо важливо для освітнього процесу, адже в ньому обов'язково слід передбачити й прогнозувати майбутній позитивний результат (Вітвицька, 2011, с. 220). 